\title{
Synthesis, Physicochemical and Antimicrobial Properties of Co (II) and Ni (II) metal complexes of the Schiff base of isatin and 4-methylaniline
}

\author{
1*IKOTUN, AA; ${ }^{1}$ OLADIMEJI, AO; ${ }^{2}$ OLURANTI, OO
}

\author{
${ }^{I}$ Department of Chemistry and Industrial Chemistry, ${ }^{2}$ Department of Biological Sciences Bowen University, Iwo, Nigeria \\ *Corresponding Author Email: ikotunadebomi@gmail.com
}

\begin{abstract}
Schiff bases derived from isatin are of great importance due to their wide applications as synthetic precursors and biological applications. The Schiff base of isatin and 4-methylaniline $\left(\mathrm{C}_{15} \mathrm{H}_{12} \mathrm{~N}_{2} \mathrm{O}\right.$; L $)$ was prepared by stirring at room temperature (using ratio 1:1) in methanol. $\mathrm{Co}\left(\mathrm{CH}_{3} \mathrm{COO}\right)_{2} .4 \mathrm{H}_{2} \mathrm{O}$ and $\mathrm{Ni}\left(\mathrm{CH}_{3} \mathrm{COO}\right)_{2} .4 \mathrm{H}_{2} \mathrm{O}$ were separately refluxed with the Schiff base (Metal:Ligand =1:3) in toluene to give their respective metal complexes. Physicochemical properties of the prepared compounds were determined using Infra-red and Electronic Spectra analyses, as well as melting point determinations. Thein-vitro antimicrobial activities of $\mathrm{L}$ and its metal complexes were evaluated against three Gram positive bacteria (Enterococcus faecalis, Micrococcus luteus and Staphylococcus aureus) and three Gram negative bacteria (Escherichia coli, Salmonella typhi and Pseudomonas aeruginosa). They showed more activities against the tested Gram positive bacteria than the Gram negative bacteria. The minimum inhibitory concentration (MIC) of Co (II) and $\mathrm{Ni}$ (II) complexes was $5 \mu \mathrm{g} / \mathrm{mL}$, while that of L was $2.5 \mu \mathrm{g} / \mathrm{mL}$. All the test bacteria were susceptible to the compounds except $S$. aureus and $E$. coli. The synthesized compounds also had antifungal potentials.
\end{abstract}

\section{DOI: https://dx.doi.org/10.4314/jasem.v23i11.8}

Copyright: Copyright $(\mathrm{C} 2019$ Ikotun et al. This is an open access article distributed under the Creative Commons Attribution License (CCL), which permits unrestricted use, distribution, and reproduction in any medium, provided the original work is properly cited.

Dates: Received: 07 October 2019; Revised: 11 November 2019; 24 November 2019

Keywords: Isatin,4-methylaniline, Schiff base, $\mathrm{Co}(\mathrm{II}), \mathrm{Ni}(\mathrm{II})$ metal complexes.

The study of isatin (indole-2,3-dione), its Schiff bases and complexes has received so much attention in recent times due to its versatility as a reagent in synthesis, to obtain heterocyclic compounds, and as a raw material for drugs (Abele et al., 2003). Its tautomeric forms consist of a lactam-carbonyl $(\alpha)$ and<smiles>CC1CCCCC1</smiles>

Scheme 1: Keto-enoltautomeric forms of isatin a keto-carbonyl $(\beta)$ as presented in Scheme 1 (Hong et al., 2003). Several novel Schiff bases of isatin have been reported with a variety of pharmacological actions, including antimicrobial and antiviral activities (Medvedev et al., 1996).<smiles>O=C1C(O)=Nc2ccccc21</smiles>

Metal complexes of isatin Schiff bases have been reported with several biological applications (Singh et al., 2005; Chohan et al., 2006; Adetoye et al., 2009; Ikotun et al., 2019; Ikotun and Omolekan, 2019). The significance of these metal complexes of isatin derivatives has also been extended to the design of novel anticancer drugs (Rodriguez-Arguelles et al., 2004). Thus the need to prepare new complexes of isatin with great biological significance is the propelling force for this research. Therefore the objective of this paper is to synthesize Co (II) and Ni (II) metal complexes of the Schiff base of isatin and 4methylaniline and evaluate their physicochemical and antimicrobial properties.

\section{MATERIALS AND METHODS}

Chemical: Isatin, 4-methylaniline, $\mathrm{Co}\left(\mathrm{CH}_{3} \mathrm{COO}\right)_{2} .4 \mathrm{H}_{2} \mathrm{O}, \quad \mathrm{Ni}\left(\mathrm{CH}_{3} \mathrm{COO}\right)_{2} .4 \mathrm{H}_{2} \mathrm{O}$ and sulphuric acid were obtained from Aldrich. The solvents used (ethanol, methanol, chloroform, acetone, dichloromethane, pyridine, diethyl ether, n-hexane, and $N, N$-dimethylformamide; DMF) were purchased as analytical grades from Sigma-Aldrich and SAARChem.

Instrumentation: Infrared spectra were recorded on Agilent Cary 630 FTIR spectrometer and the UVVisible spectra were recorded on a Shimadzu UV1800 spectrometer. The purity of the compounds were 
checked by Thin-Layer Chromatography (TLC) carried out on Silica Gel 60 F254 alumina plates (E Merk) using appropriate solvent mixtures of diethyl ether: petroleum ether or chloroform as the eluent and visualized in UV chamber $(365 \mathrm{~nm})$. Melting points were determined using a Gallen kemp variable heater apparatus.

Preparation of isatin and 4-methylanline Schiff base $(L)$ : Isatin (2.00 g; $0.01359 \mathrm{~mol})$ was dissolved in methanol $(60 \mathrm{~mL})$. 4-methylaniline $(1.46 \mathrm{~g} ; 0.01359$ mol) was then added gradually while stirring at room temperature. The reaction was acid catalyzed with 5 drops of conc. $\mathrm{H}_{2} \mathrm{SO}_{4}$. Stirring was done for about 60 min and the light yellow product formed was filtered out under suction, washed with methanol, dried, weighed and kept in the dessicator.

Preparation of the metal complexes: The metal complexes were prepared by the addition of $0.14 \mathrm{~g}$ $(0.000563 \mathrm{~mol})$ of $\mathrm{Co}\left(\mathrm{CH}_{3} \mathrm{COO}\right)_{2} .4 \mathrm{H}_{2} \mathrm{O}$ and $0.14 \mathrm{~g}$ $(0.000563 \mathrm{~mol})$ of $\mathrm{Ni}\left(\mathrm{CH}_{3} \mathrm{COO}\right)_{2} .4 \mathrm{H}_{2} \mathrm{O}(0.14 \mathrm{~g})$ separately dissolved in toluene $(10 \mathrm{ml})$ to a stirring solution of $0.4 \mathrm{~g}(0.00169 \mathrm{~mol})$ of $\mathrm{L}$ in $50 \mathrm{ml}$ toluene. Each of the reaction mixture was refluxed for $2 \mathrm{~h}$ and the products that precipitated out were filtered (after cooling), washed with toluene, dried and stored in the dessicator.

Antimicrobial Activity: The antimicrobial potentials of the synthesized compounds were tested against some bacteria and fungi using disc-diffusion method. Mueller Hinton agar was used for the bacterial isolates (Enterococcus faecalis, Micrococcus luteus, Staphylococcus aureus, Escherichia coli, Salmonella typhi, Pseudomonas aeruginosa), while potato dextrose agar was used for the fungi (Aspergillus niger, Aspergillus flavus, Aspergillus fumigatus, Candida albicans). The isolates were previously confirmed by various biochemical tests in the Microbiology Laboratory of the Department of Biological Sciences, Bowen University, using the methods described by Cheesbrough (2002). The fungi were identified using their macroscopic and microscopic features. Streptomycin $(10 \mu \mathrm{g} / \mathrm{disc})$ was used as the standard drug for the test bacteria while ketoconazole $(10 \mu \mathrm{g} / \mathrm{disc})$ was used for the fungi. Dimethylformamide (DMF) used in dissolving the compounds served as control.

Antibacterial test: Peptone water (15 g in 1 liter) and Mueller Hinton agar (38 g in 1 liter) were prepared. A loop full of inoculum from each bacterial culture was inoculated at $37{ }^{\circ} \mathrm{C}$ for $18-24 \mathrm{~h}$. The concentration of the bacterial suspension was estimated using 0.5 McFarlard standard of about $10^{8}$ cells $/ \mathrm{mL}$. Sterile normal saline was added to adjust the concentration. The synthesized compounds were dissolved in DMF at a concentration of $10 \mu \mathrm{g} / \mathrm{ml}$. sterile swab sticks were used in streaking each suspension on the solidified Mueller Hinton agar. Sterile Whatman filter paper discs (5 mm diameter size) impregnated with the synthesized compounds were aseptically placed on the agar surface. These were allowed to diffuse well into the agar before incubation at $37{ }^{\circ} \mathrm{C}$ for $24 \mathrm{~h}$. The experiment was carried out in triplicates. All the plates were observed for zones of inhibition in both tests and controls according to the procedure described by Jonathan et al., 2008.

Minimum inhibitory concentration (MIC): The MIC of the compounds was determined using different concentrations; $5.0,2.5,1.0 \mu \mathrm{g} / \mathrm{ml}$. This test was carried out on bacteria which had inhibitory zones against the compounds. The plates were incubated at $37^{\circ} \mathrm{C}$ for $18-24 \mathrm{~h}$. This was the least concentration of the compound that hindered the growth of the test microorganisms.

Antifungal test: Fungal isolates were inoculated into sterile liquid medium containing ammonium chloride, magnesium sulphate, dipotassium hydrogen phosphate, ferric citrate, starch and yeast in distilled water and incubated at $25{ }^{\circ} \mathrm{C}$ for 3 days. The fungal suspension were standardized to an optical density of $0.1(\wedge=600 \mathrm{~nm})$ using spectrophotometric method before use. About $100 \mu \mathrm{L}$ of the suspension were spread uniformly on the surface of PDA plates using a glass hockey stick. The impregnated discs were also placed on the agar surface before incubating at $25{ }^{\circ} \mathrm{C}$ for 3 days. Plates were observed for inhibitory zones. Average of the values obtained in triplicates was recorded for each of the fungi.

\section{RESULTS AND DISCUSSION}

The ligand and its metal complexes have been successfully prepared. The ligand was synthesized at room temperature, while its metals were synthesized by refluxing method. The equation for the preparation of the ligand is presented as Scheme 2. The general equation for the preparation of the metal complexes, similar to that of literature (Adetoye et al., 2009), is presented as Scheme 3. The physical properties of the ligand and its complexes are presented in Table 1.

Solubility Test: The prepared ligand ant its complexes were soluble in water, dimethylsulphoxide (DMSO) and dimethylformamide (DMF), but sparingly soluble in acetone.

Infrared spectra of $L$ and its metal Complexes: The characteristic vibrational frequencies in the infrared 
spectra have been identified by comparing the spectrum of the Schiff base with the spectra of the Co (II) and Ni(II) complexes. These spectra analyses are presented in Table 2. The absorption bands have been assigned by comparing the spectra of these compounds
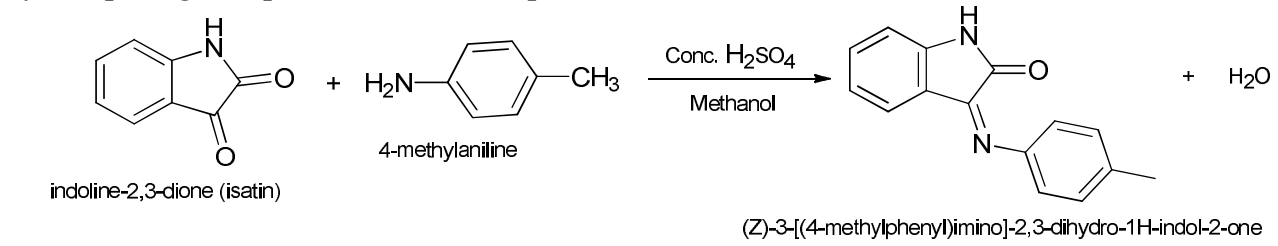

Scheme 2: Scheme for the preparation of the ligand

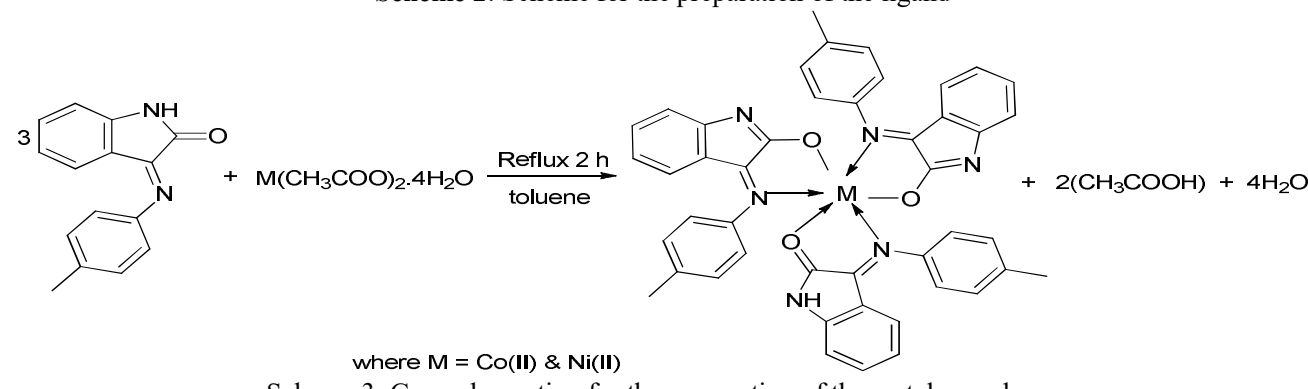

Scheme 3: General equation for the preparation of the metal complexes

Table 1: Some physical properties of $\mathrm{L}\left(\mathrm{C}_{15} \mathrm{H}_{12} \mathrm{~N}_{2} \mathrm{O}\right)$ and its complexes

\begin{tabular}{llll}
\hline Compound & Colour & Melting point $\left({ }^{\mathbf{0}} \mathbf{C}\right)$ & \% Yield \\
\hline $\mathrm{L}\left(\mathrm{C}_{15} \mathrm{H}_{12} \mathrm{~N}_{2} \mathrm{O}\right)$ & Light yellow & $198-200$ & 72 \\
$\mathrm{Co}$ (II) complex & Dark brown & $>320$ & 60 \\
$\mathrm{Ni}$ (II) complex & Orange & $>320$ & 45 \\
\hline
\end{tabular}

Table 2: Relevant Infrared Spectral Data of Ligand and its metal Complexes

\begin{tabular}{lllllll}
\hline Compound & $\begin{array}{l}v(\mathrm{OH}) \\
\left(\mathrm{cm}^{-1}\right)\end{array}$ & $\begin{array}{l}v(\mathrm{NH}) \\
\left(\mathrm{cm}^{-1}\right)\end{array}$ & $\begin{array}{l}v(\mathrm{C}=\mathrm{O}) \\
\left(\mathrm{cm}^{-1}\right)\end{array}$ & $\begin{array}{l}v(\mathrm{C}=\mathrm{N}+\mathrm{C}=\mathrm{C}) \\
\left(\mathrm{cm}^{-1}\right)\end{array}$ & $\begin{array}{l}v\left(\mathrm{CH}_{\text {hasl }}\right) \\
\left(\mathrm{cm}^{-1}\right)\end{array}$ & $\begin{array}{l}v(\mathrm{C}-\mathrm{N}+\mathrm{C}-\mathrm{C}) \\
\left(\mathrm{cm}^{-1}\right)\end{array}$ \\
\hline $\mathrm{L}\left(\mathrm{C}_{1} \mathrm{H}_{12} \mathrm{~N}_{2} \mathrm{O}\right)$ & - & 3244 & $1739 \mathrm{~s} 1720 \mathrm{~s}$ & $1607 \mathrm{~s} 1592 \mathrm{~s}$ & $1459 \mathrm{~s}$ & $1105 \mathrm{~m}$ \\
$\mathrm{Co}(\mathrm{II})$ Complex & $3312 \mathrm{w}$ & $3050 \mathrm{w}$ & $1750 \mathrm{~m}$ & $1605 \mathrm{~s} 1560 \mathrm{~s}$ & $1459 \mathrm{~m}$ & $1107 \mathrm{w}$ \\
$\mathrm{Ni}$ (II) Complex & $3466 \mathrm{w}$ & $3050 \mathrm{~m}$ & $1724 \mathrm{~s}$ & $1625 \mathrm{~m}-1608 \mathrm{~m}$ & $1465 \mathrm{~s}$ & $1081 \mathrm{w}$ \\
\hline
\end{tabular}

Note: $v$ stretching; $\mathrm{s}$ - Strong, $\mathrm{m}$ - medium, $\mathrm{b}$ - broad and $\mathrm{w}$ - weak

The FTIR spectrum of $\mathrm{L}\left(\mathrm{C}_{15} \mathrm{H}_{12} \mathrm{~N}_{2} \mathrm{O}\right)$ showed a medium intensity band at $3244 \mathrm{~cm}^{-1}$ attributed to $v(\mathrm{NH})$ vibrational frequency. This band appeared as either a weak or a medium band at a lower frequency of $3050 \mathrm{~cm}^{-1}$ in its complexes. The strong bands that appeared at 1732 and $1720 \mathrm{~cm}^{-1}$ were attributed to the $\mathrm{v}(\mathrm{C}=\mathrm{O})$ stretching vibration. One of these bands disappeared in both complexes, while the other has undergone a shift to a higher frequency of $1750 \mathrm{~cm}^{-1}$ in the spectrum of its Co (II) complex and a shift to a lower frequency of $1724 \mathrm{~cm}^{-1}$ in the spectrum of the Ni (II) complex. These signify the involvement of the isatin oxygen in coordination. The spectrum of $\mathbf{L}$ showed a strong and a medium band at 1607 and 1592 $\mathrm{cm}^{-1}$ attributed to uncoordinated $\mathrm{C}=\mathrm{N}$ and $\mathrm{C}=\mathrm{C}$ stretching vibrations, $v(C=N+C=C)$, which appear as overlapped bands. These bands have moved to lower frequencies of 1605 and $1560 \mathrm{~cm}^{-1}$ in the spectrum of the Co (II) complex, while they moved to higher frequencies of 1625 and $1608 \mathrm{~cm}^{-1}$ in the spectrum of the $\mathrm{Ni}$ (II) complex. This also signifies the involvement of the imine nitrogen in coordination. The strong band appearing at $1459 \mathrm{~cm}^{-1}$ in the spectrum of $\mathbf{L}$ was attributed to the $v(\mathrm{CH}$ bend $)$ vibration and the frequency has remained unchanged in the $\mathrm{Co}$ (II) complex, while it shifted to a higher frequency of $1465 \mathrm{~cm}^{-1}$ in the spectrum of its $\mathrm{Ni}$ (II) complex. The medium band appearing at $1105 \mathrm{~cm}^{-1}$ in the spectrum of $\mathbf{L}$ was attributed to $v(\mathrm{C}-\mathrm{N}+\mathrm{C}-\mathrm{C})$ stretching vibration. This band has appeared as a weak band at $1107 \mathrm{~cm}^{-1}$ in the spectrum of the Co (II) complex, while it appeared at $1081 \mathrm{~cm}^{-1}$ in the spectrum of the Ni(II) complex. All these confirm the formation of the $\mathrm{Co}$ (II) and $\mathrm{Ni}$ (II) complexes of this ligand. The FTIR spectra of these compounds are presented as Figures 1 to 3 .

$U V$-visible Spectra of the ligand and its metal complexes: The UV-visible spectra analyses of the ligand and its complexes have been presented as Table 3. The electronic spectra data of the ligand and complexes are presented in Table 4. 


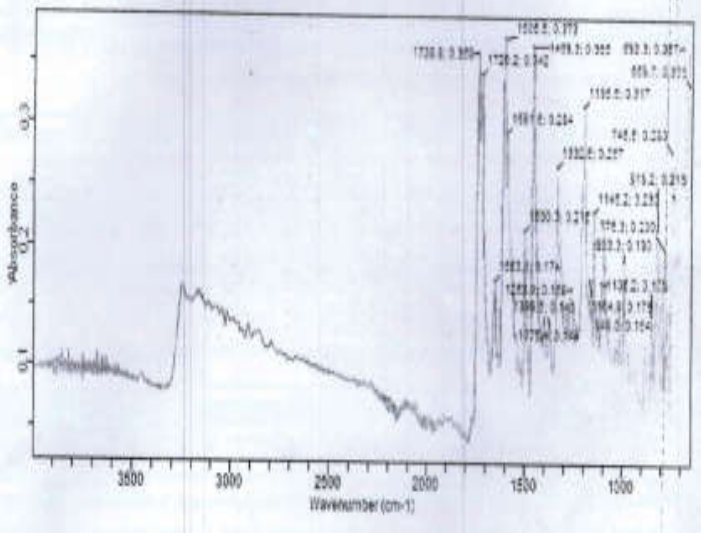

Fig 1: FTIR Spectrum of the Ligand

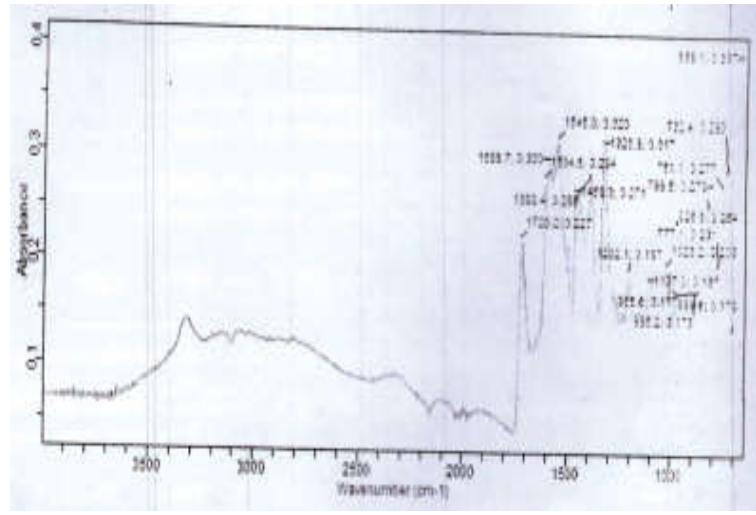

Fig 2: FTIR Spectrum of the Co(II) Complex

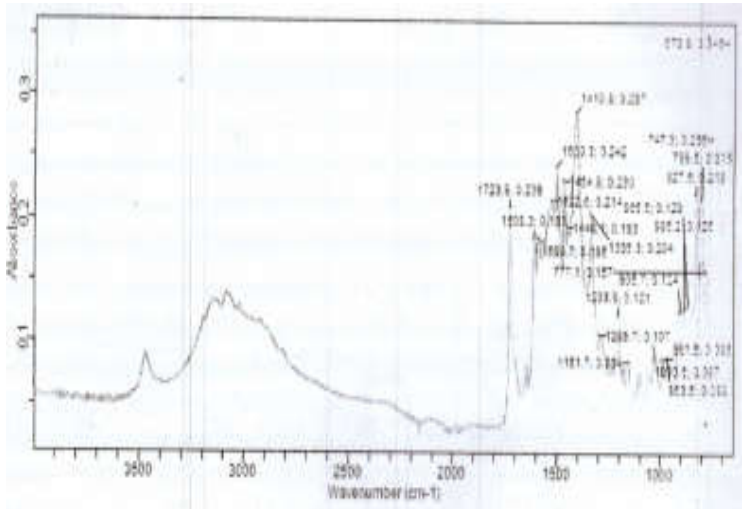

Fig 3: FTIR Spectrum of the Ni(II) Complex

The ultraviolet spectrum of the ligand showed an absorption band at $268 \mathrm{~nm}$, which has been assigned to $\pi-\pi^{*}$ transition. The absorption bands at $262 \mathrm{~nm}$, $206 \mathrm{~nm}$ and $194 \mathrm{~nm}$ were attributed to $\mathrm{n}-\pi^{*}$ transitions. The interpretations of ultraviolet spectra of metal complexes of this type of isatin derived Schiff bases revealed that charge transfer bands occur in the same region with $\pi-\pi^{*}$ transitions (Chohan et al., 2006; Adetoye et al., 2009). The spectra of the Co (II) complex showed an absorption band at $300 \mathrm{~nm}$, which was assigned as $\pi-\pi^{*}$ transition. Also, the absorption bands at $288 \mathrm{~nm}$ and $274 \mathrm{~nm}$ have been assigned as $\mathrm{n}$ $-\pi^{*}$ transitions. In the spectra of the Ni (II) complex, the band at $265 \mathrm{~nm}$ has been assigned as $\pi-\pi^{*}$ transition. The bands at $261 \mathrm{~nm}$ and $246 \mathrm{~nm}$ have been assigned as $n-\pi^{*}$ transitions. The electronic spectra of these prepared compounds are presented as Figures 4 to 6 .

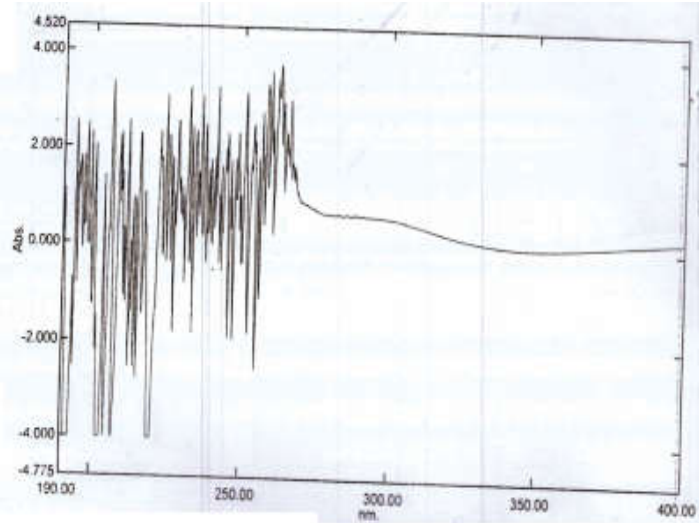

Fig 4: UV-Visible Spectrum of the Ligand

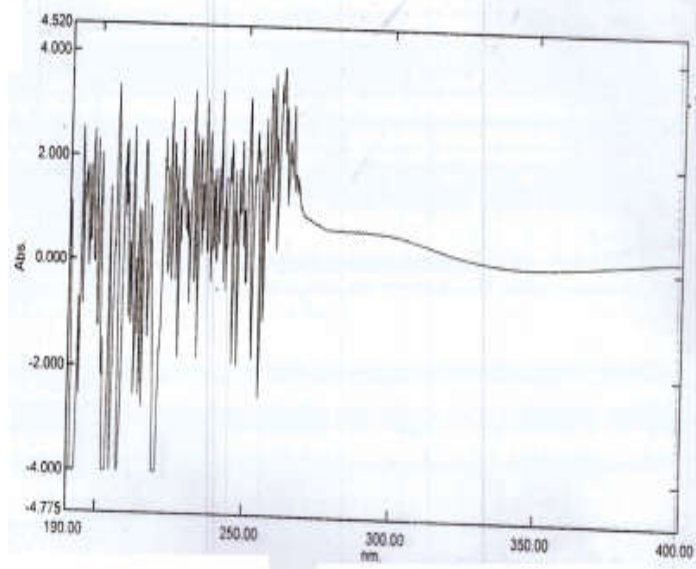

Fig 5: UV-Visible Spectrum of the Co(II) Complex

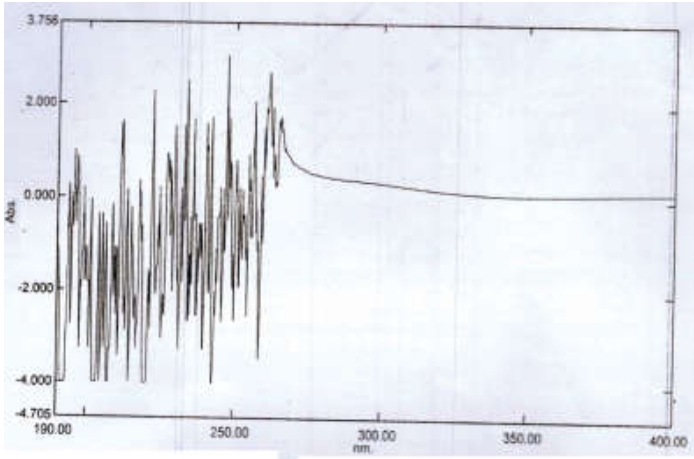

Fig 6: UV-Visible Spectrum of the Ni(II) Complex 
Table 3: UV Spectra Assignments of the ligand and its metal complexes

\begin{tabular}{|lll|}
\hline Compound & Band position $(\mathrm{nm})$ & Band assignment \\
\hline Ligand $\left(\mathrm{C}_{15} \mathrm{H}_{12} \mathrm{~N}_{2} \mathrm{O}\right)$ & 268 & $\pi-\pi^{*}$ \\
& $262 ; 206 ; 194$ & $\mathrm{n}-\pi^{*}$ \\
$\mathrm{Co}(\mathrm{II})$ complex & 300 & $\pi-\pi^{*}$ \\
& $288 ; 274$ & $\mathrm{n}-\pi^{*}$ \\
$\mathrm{Ni}(\mathrm{II})$ complex & 265 & $\pi-\pi^{*}$ \\
& $261 ; 246$ & $\mathrm{n}-\pi^{*}$ \\
\hline
\end{tabular}

Antimicrobial Activities: The results of the antimicrobial and antifungal activities of the synthesized compounds and the standard antibiotics have been presented as Bar charts 7 and 8 respectively. All the test bacteria were susceptible to the compounds except $S$. aureus and E. coli (Figure 7). Also, the compounds showed more activities against Gram positive bacteria (Enterococcus faecalis, Micrococcus luteusand Staphylococcus aureus) than Gram negative bacteria (Escherichia coli, Salmonella typhi, Pseudomonas aeruginosa). Co (II) and the ligand showed activities against Pseudomonas areuginosa with high zones of inhibitions. The synthesized compounds all had reasonable antifungal potentials.

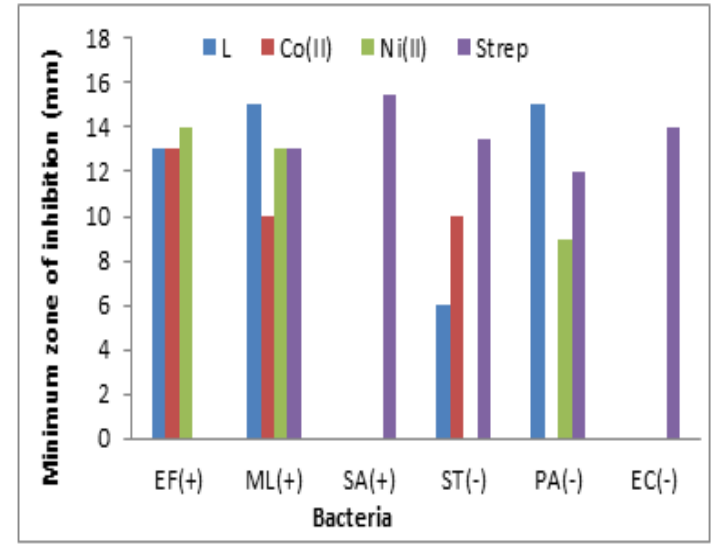

Note: $E F(+)=$ Enterococcus faecalis; $M L(+)=$ Micrococcus luteus; $S A(+)=$ Staphylococcus aureus; $S T(-)=$ Salmonella typhi PA(-) = Pseudomonas aeruginosa; EC(-) = Escherichia coli

Fig 7: Comparison of the antibacterial activities of the ligand and its metal complexes

All the fungi were susceptible to the compounds except $A$. niger, which was resistant to Co (II) complex. However, the standard antifungal drug, ketoconazole had better activity against the fungi than the test compounds. In accordance with results obtained in this study, Joseyphus and Nair (2009) have also reported that their ligand showed the best antimicrobial activities against their test bacteria and fungi. The antibacterial and antifungal activities of the ligand and its complexes indicate that they are effective against the bacterial and fungal isolates. The minimum inhibitory concentration (MIC) of Co (II) and $\mathrm{Ni}$ (II) complexes was $5 \mu \mathrm{g} / \mathrm{mI}$ (Table 4). This was the lowest concentration required to inhibit the growth of the tested microbes. Also, the MIC of ligand was $2.5 \mu \mathrm{g} / \mathrm{mI}$. Therefore it had the best activity against the test bacteria.

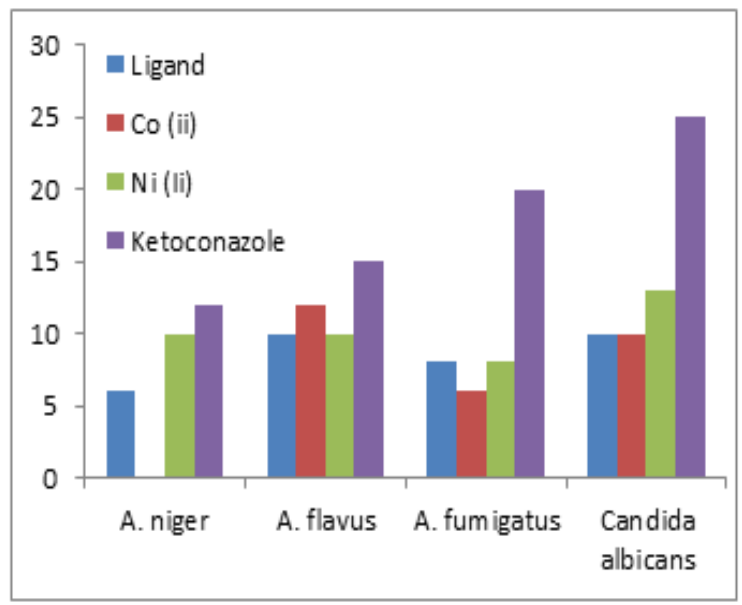

Fig 2: Antifungal activities of the ligand and its metal complexes

Table 4: MIC results for the compound with the highest zone of inhibition against each of the bacteria

\begin{tabular}{|lll|}
\hline Bacteria & Compound & $\mathrm{MIC}(\mu \mathrm{g} / \mathrm{ml})$ \\
\hline Enterococcus faecalis $(+)$ & $\mathrm{Ni}(\mathrm{II})$ & 5 \\
Salmonella typhi $(-)$ & $\mathrm{Co}(\mathrm{II})$ & 5 \\
Pseudomonas aeruginosa $(-)$ & $\mathrm{L}$ & 2.5 \\
\hline
\end{tabular}

Conclusion: The ligand, L, has been successfully prepared alongside its $\mathrm{Co}$ (II) and $\mathrm{Ni}$ (II) metal complexes. L is a bidentate ligand, which possesses an oxygen and a nitrogen donor atoms. Therefore it is expected to coordinate through the azomethine $\mathrm{N}$ and $\mathrm{O}$ atoms on the isatin group. Spectra analyses revealed the formation of the new Co (II) and Ni (II) complexes of this ligand. Antimicrobial studies also showed that these prepared compounds can be used as drugs against the tested pathogens, as associates or alternatives to the tested antibiotics.

Acknowledgement: The Royal Society of Chemistry (RSC) is appreciated for providing funds for this research.

\section{REFERENCES}

Abele, E.; Abele, R.; Dzenitis, O. and Lukevics, E. (2003). Indole and Isatin Oximes: Synthesis, 
Reactions and Biological Activity. Chem. Heterocycl. Comp. 39:3-35.

Hong Miu M. A; Zhan Zhu LIU, Shi Zhi Chen (2003). New approach to synthesis of 6,7dimethoxyisatin. Chinese Chemical Letters, 14: $468-470$

Adetoye A A.; Egharevba G O; Obafemi C A. and Kelly D R (2009). Synthesis and physicochemical properties of $\mathrm{Co}(\mathrm{II}), \mathrm{Cu}(\mathrm{II}), \mathrm{Fe}(\mathrm{III}), \mathrm{Mn}$ (II) and $\mathrm{Ni}(\mathrm{II})$ complexes of isatin derivative of sulfanilamide. Toxicol. Environ. Chem. 91, (5): 837846.

Cheesbrough M. (2002). Biochemical tests to identify bacteria. In: Laboratory practice in tropical countries. CheesbroughM (ed.). Cambridge Edition, 63-87

Chohan, Z H; Shaikh, A U and Naseer, M M. (2006). Metal-based isatin-bearing Sulfonamides: their synthesis, characterization and biological properties. Appl. Organometal. Chem., 20: 729739

Ikotun, A A, Coogan, M P, Owoseni, A A and Egharevba, G O (2019). Design, synthesis, physicochemical and antimicrobial properties of rhenium (I) tricarbonyl complexes of 3(phenylimino)indole-2-one. J. Chem. Soc. Nigeria, 44 (5), 948-958.

Ikotun, A A and Omolekan, O O (2019). Microwaveassisted Synthesis, Characterization, Antimicrobial and Antioxidant Activities of 1Benzyl-3-[(4-Methylphenyl)Imino]-Indolin-2one and Its Co(II) Complex. Chem. Sci. Inter. J. $28(1), 1-12$
Jonathan, S G, Kigigha, L T and Ohiamain, E (2008). Evaluation of the inhibitory potentials of eight edible higher Nigerian fungi against pathogenic microorganisms. African Journal of Biomed Sc. 11: $195-200$

Joseyphus, R S and Nair, M S (2009) Synthesis, characterization and antimicrobial activities of translation metal complexes with the Schiff base derived from imidazole-2-carboxaldehyde and glycylglycine. Journal of Coordination Chemistry 62 (2): 319-327

Medvedev, A G; Clow, A.; Sandler, M. and Glover, V. (1996). Isatin - a link between natriuretic peptides and monoamines? Biochem. Pharmacol. 52: 385391

Rodriguez-Arguelles, M C.; Ferrari, M B.; Bisceglie, F P G.; Pelosi, G.; Pinelli, S. and Sassi, M. (2004). Synthesis, characterization and biological activity of $\mathrm{Ni}, \mathrm{Cu}$ and $\mathrm{Zn}$ complexes of isatin hydrazones. J. Inorg. Biochem. 98: 313-321.

Singh, R V; Fahmi, N and Biyala, M K (2005). Coordination behavior and biopotency of $\mathrm{N}$ and $\mathrm{S} / \mathrm{O}$ donor ligands with their Paladium(II) and Platinum(II) complexes. J. Iranian Chem. Soc. 2: 40-46. 